Trakya Eğitim Dergisi

Cilt 10 Sayı 3

Eylül 2020, 632-646

Geliş Tarihi: 01.06.2019.

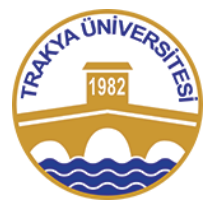

ISSN: $2630-6301$

Doi: $10.24315 /$ tred.573373

Araştırma Makalesi/

Research Article
Trakya Journal of Education

Volume 10, Issue 3

September 2020, 632-646.

Yayına Kabul Tarihi:11.05.2020.

\title{
İkinci Yabancı Dil Olarak Almanca Eğitiminde Öğrenme Stillerinin Belirlenmesi
}

\section{Determination of Learning Styles in German Education As Second Foreign Language}

\section{Bahar EREN ${ }^{1}$, Handan KÖKSAL ${ }^{2}$}

ÖZ: Araştırmanın amacı, 2016-2017 eğitim öğretim y1lında Edirne il merkezindeki özel bir okulda L3 (Almanca) dersi gören 4., 5. ve 6. sinıf öğrencilerinin $(\mathrm{n}=111)$ öğrenme stillerini belirlemektir. Öncelikle L3 öğrenen öğrencilerin L1 (Türkçe), L2 (İngilizce) öğrenme stilleri belirlenmeye çalışılmıştır. Araştırmada, öğrenme stili kavramı L1, L2 ve L3'de nedir? sorusunun yanıtı aranmıştır. $\mathrm{Bu}$ araştırmada nitel araştırma yöntemlerinden durum çalışması deseninden yararlanılmıştır. Öğrencilere yönelik çalışmada Aşkar ve Akkoyunlu (1993) tarafindan Türkçeye uyarlanan "Kolb Öğrenme Stilleri Ölçeği" kullanılmıştır. Öğrencilerle ayrıca bireysel ve odak grup görüşmeleri yapılıp, öğrenci ürünleri öğrenme stilleri açısından incelenmiştir. Okuldaki, bir Türkçe, bir İngilizce ve bir Almanca öğretmeniyle bireysel görüşmeler de yapılmıştır. Ölçekten elde edilen veriler L1, L2 ve L3'ün birbirlerine olan etki alanları açısından nitel ve nicel olarak değerlendirilmiştir. Araştırmada öğrencilerin L1, L2 ve L3 derslerinde benzer öğrenme stili özellikleri gösterdikleri sonucuna ulaşılmıştır.

Anahtar sözcükler: Ana Dilde Öğrenme Stili, Birinci Yabancı Dilde Öğrenme Stili, İkinci Yabancı Dilde Öğrenme Stili, Yaşam Boyu Öğrenme

\begin{abstract}
The aim of the study was to determine the learning styles of the 4 th, 5 th and 6th grade students $(n=111)$ in L3 (German) at a private school in the city center of Edirne in the academic year 2016-2017. First of all, L1 (Turkish), L2 (English) learning styles of L3 students were determined. What is the concept of learning style L1, L2 and L3? The answer to the question has been sought. A case study pattern was used from qualitative research methods. Individual and focus group interviews were conducted with students and student products were examined in terms of learning styles. Individual interviews were conducted with a Turkish, an English and a German teacher at the school. In this study, Kolb Learning Styles Scale (which was adapted to Turkish by Aşkar and Akkoyunlu (1993) was used. The data obtained from the scale were evaluated qualitatively and quantitatively in terms of the effect areas of L1, L2 and L3. In the research, it was concluded that the students showed similar learning style characteristics in L1, L2 and L3 courses.
\end{abstract}

Keywords: Learning Style in Mother Tongue, Learning Style in First Foreign Language, Learning Style in Second Foreign Language, Lifelong Learning

Bu makaleye atıf vermek için:

Eren, B. \& Köksal, H. (2020). İkinci yabancı dil olarak Almanca eğitiminde öğrenme stillerinin belirlenmesi. Trakya Eğitim Dergisi, 10(3), 632-646.

Cite this article as:

Eren, B. \& Köksal, H. (2020). Determination of learning styles in German education as second foreign language. Trakya Journal of Education, 10(3), 632-646.

\section{Introduction}

\section{EXTENDED ABSTRACT}

The aim of this study is to determine learning styles in second foreign language education. For this purpose, it was studied to determine the learning styles used for the 4th, 5th and 6th grades in the mother tongue (L1), in the first foreign language (L2) and in the second foreign language (L3). In the study, the thoughts of many people about the importance of learning styles are included. Learning styles are individual. It is natural for each student to have a different learning style.

Nowadays, language education has not been limited to certain periods of human life and even the most developed countries have been seeking to continuously improve their education systems and to improve the quality of education. In this context, the concept of lifelong learning, which allows individuals to learn the knowledge and skills they need at any age, has gained importance.

A student who has a good understanding of the mother tongue's functional characteristics can use the messages he/ she receives while learning other languages more accurately to his / her perception. In this way, the student can decide which techniques and methods he / she is using in his / her mothertongue education studies and can use these methods in learning foreign language. When the individual

1 Beykent Koleji, e-posta: bahareren60@gmail.com, ORCID: 0000-0003-2664-7331

2 Doç. Dr., Trakya Üniversitesi Eğitim Fakültesi, e-posta: handankoksal@trakya.edu.tr, ORCID: 0000-0002-6083-4723 
knows the style of his / her learning, he / she will activate this style in the learning process. Thus, you will learn more easily and more quickly and most likely will be successful in the learning process. Learning success can be proportional to learning styles. L3 and L2 language learners are able to realize their learning process by taking advantage of the learning styles they have acquired. Thus, learning environments suitable for students' needs can also be provided. The difficulties faced by a teacher who wants to teach a lesson according to their learning styles can be reduced and the quality of education can be increased.

\section{Method}

The research was designed as a case study. Case studies, which are a qualitative research design, are frequently used in scientific research. While carrying out the case study for the determination of learning styles in the second foreign language, the qualifications of Yin for the structure validity were taken as the basis. Methodological diversity, data source variation, detailed descriptions and regular observation strategies were used in the study. In this study, both quantitative and qualitative data were collected. In the study, quantitative data were collected through the Kolb Learning Styles Inventory, which was translated by Aşkar and Akkoyunlu (1993) and by the personal information form created by the researcher. Kolb Learning Styles Inventory was used to determine the learning styles of 4th, 5th and 6th grade students in L1, L2 and L3. The personal information form was used to determine the age, class, gender, L1, L2 and L3 information of the students, their success in L1, L2 and L3, and their learning style of L1, L2 and L3. In addition, the visual products that students have created are depicted. Only individual interviews were held with the teachers and individual and focus group interviews were held with the students. The interviews were recorded in the researcher's book and recorded. In addition to these studies, in order to ensure internal validity, it was also possible for another researcher in the classroom to collect data and to compare the findings. These external observations were noted again in the researcher's book. As a result of content analysis by the researcher, all works for the conceptualization of qualitative data were evaluated and themes and sub-themes were decided. Qualitative data were evaluated for the explanatory and confirmatory domain of quantitative data. The use of the Kolb Learning Styles Inventory, which was translated by Aşkar and Akkoyunlu (1993) and tested the reliability validity, for L1, L2 and L3 was calculated by the expert with the help of SPSS 22.0 package program.

\section{Findings}

At the end of the research it is concluded that the students show similar learning styles are presented for L1, L2 and L3 lessons. Furthermore it is specified that three teachers lecturing the L1, L2 and L3 include activities regarding the learning style. Another observation conclusion is that positive transfer is available regarding learning style between L1, L2 and L3 languages. L1 teachers should explore the learning styles of students at an early age. Because the L1 environment is a learning environment in which students are most comfortable in their cognitive sense. Later, with the interdisciplinary learning, these experiences are transferred from L1 to L2 and L3. It should also be investigated whether children's learning styles change as the learning process progresses in foreign language education. It should be noted that L1, L2 and L3 languages provide positive transfer among themselves. In-class transfers between languages should be used. In the environments where different course materials are available, the presence of classroom environments addressing each student's style can direct them to the learning process and increase the student's motivation for learning foreign languages. For this reason, teachers should be aware of the student's learning styles. Learning styles in L3 should be examined in more depth. Further studies should be included in the literature.

\section{Result and Discussion}

Learning styles show similarities and differences in L1, L2 and L3. L1, L2 and L3 provide positive transfers to each other. Teachers should know their students' learning styles and prepare activities accordingly. The quantitative findings of the study show that the students have high awareness about learning styles in L3. The same applies to L1 and L2 courses. The findings show that teachers have sufficient knowledge of their learning styles and raise awareness about their learning styles in their schools. In L1 education, the inputs of the students are shaped in the direction of learning styles and this can be valid in the next foreign languages. Therefore, experience gained in L1 training is very important. Learning styles that the 11 student is aware of can contribute to L2 and L3. Thus, it may be more practical to learn a foreign language by a positive transfer between languages. The qualitative findings of the study show that students have gained awareness of their learning styles and that teachers prepare their 
classroom activities according to their learning styles. Teachers stated that they were aware of the learning styles in individual group interviews and they included activities for learning styles in the courses. At the same time, the expressions obtained from the individual and focus group interviews with the students indicate that students are aware of their learning styles. Course observations for students and teachers by a researcher and an assistant participant also confirm that a learning environment for learning styles is provided. In the study, quantitative and qualitative findings support each other.

Students will be able to assess their strengths and limitations to support their learning and personal development. Thus, students gain the necessary skills for inquiry and research and are aware of their own learning styles in learning. Students who are aware of their own learning styles enjoy learning, and this learning curiosity lasts a lifetime.

\section{GİRIŞ̧}

Öğrencilerin dil öğrenirken kullandıkları farklı stratejiler vardır. Güven (2004) öğrenme stratejilerini, bireyin öğrenme sürecindeki izlediği yollar olarak tanımlamaktadır. Balcı (2013) öğrencilerin keşfedilen öğrenme potansiyellerinin değerlendirilmesi gerektiğinden söz etmektedir. Bu düşünceye göre, öğrenme stratejilerinin öğrenme stilleri ile birlikte işlenmesi, öğrenme yaşantılarının düzenlenmesine katkı sağlamaktadır. Böylece öğrenenin, mevcut öğrenme kapasitesinin maksimum düzeyde artmasını sağlamaktadır. Bireyler arasında birçok yönden öğrenme farklılığı olabileceğini bilinen bir gerçektir. Bu açıdan öğrenme ve öğretme sürecinin yabancı dil eğitimi açısından önem arz eden bireysel farklılıklardan ve öğrenme stillerinden meydana geldiği üzerinde durmaktadır. "Kolb yaşantısal öğrenme kuramına dayalı dört öğrenme stili bir döngü şeklindedir. Bu öğrenme stilleri içinde de dört öğrenme biçimi bulunmaktadır. Her bir öğrenme biçimini belirleyen öğrenme yolları birbirinden farklıdır. Bunlar sırasıyla, somut yaşantı için 'hissederek', yansıtıcı gözlem için 'izleyerek', soyut kavramsallaştırma için 'düşünerek', aktif yaşantı için 'yaparak' öğrenmedir. Her bireyin öğrenme stili bu 4 temel biçimin bileşenidir” (Akkoyunlu, 1995: 107). Öğrenme stilinin bilinmesi öğrenme sürecini de olumlu yönde hızlandırır. "Öğrenme süreci, formal eğitimdeki okul sınırlarının ötesine geçmekte ve yaşam boyu her yerde eğitim sürecine dönüşmektedir. Bu dönüşüm süreci, günümüzde eğitimi insan yaşamının belirli dönemleriyle sınırlandırılamaz bir hâle getirmiş ve en gelişmiş ülkeler bile eğitim sistemlerini sürekli geliştirme ve eğitimin niteliği arttırma arayışı içine girmişlerdir. Bu bağlamda, bireylerin gereksinim duydukları bilgi ve becerileri her yaşta öğrenebilmelerine olanak sağlayan "yaşam boyu öğrenme" kavramı önem kazanmıştır" (Ayaz, 2016: 2).

Araştırmada yer alan L1, öğrencilerin anadili olan Türkçe'yi, L2 birinci yabanc1 dil olan İngilizce'yi, L3 ise ikinci yabanc1 dil olan Almanca'yı ifade etmektedir. İkinci yabancı dilde (L3) öğrenme stillerine göre eğitim gören öğrenciler, hem anadil (L1) hem de birinci yabanc1 dil (L2) öğrenirken öğrenme stilleri konusunda farkındalık kazandırılmamış olabilirler. L1'de öğrenciler kendi öğrenme stilleri üzerine düşünmüş ve uygulamış olabilirler, ancak L2 ve L3 sürecinde bu öğrenme stillerinin bir önemi olup olmadığı veya aralarında bir etkileşim olup olmadığı konusu da irdelenmelidir. $\mathrm{Bu}$ bağlamda L3 kuramından yarar sağlanabilmektedir. Bu kuramın öncüsü olan Hufeisen ve Neuner (2003) L3'ün ortaya çıkarılması ve geliştirilmesine bağlı olarak çokdillilik ve çoklu dil edinimi konularına genel bir bakış açısı kazandırmıştır. Bu iki araştırmacıya göre çokdillilik kavramı, ikinci ve üçüncü dil arasındaki benzerlik ve farklılıkları ortaya koyarak bireye dilsel yetiler kazandırır. Burada konuşulan her bir dilin birbirinden benzer ve farklı boyutları hesaba katıldığında, çokdilliliğin bireye iletişimsel yeterlilik, söylem ve stratejik yeterlilik gibi özellikler kazandırdığından söz edilmektedir. İletişimsel yeterliliği ile birey sahip olduğu kelime dağarcığ 1 , telaffuz ve tonlama becerileriyle kendisini en rahat biçimde ifade edebilir. Birey kendini sözlü veya yazılı dilde en doğru şekilde ifade ederek söylem becerisini gerçekleştirir. Bireyin stratejik yeterliliği ise dilini nerede, ne zaman ve nasıl kullanacağını planlaması ile doğru orantılıdır. Böylece birey, birbirinden farklı dillerden kazandığı yetkinlikler ile çok dilli bir sözlük olup, çok dilli analiz yeteneği elde eder.

Neden yabancı dil öğrenildiği sorusu üzerinde düşünüldüğünde, diller arası ilişkilerin boyutlarından söz edilebilir. "İnsanlar, toplumlar ve milletler arasında kişisel, kurumlar arası ve devletler seviyesinde çeşitli ilişkiler bulunmaktadır. Bilim, siyaset, askerlik, eğitim, turizm, kültür, sanat, ticaret ve iletişim alanlarındaki bu ilişkilerin sağlıklı olarak yürütülebilmesi için ana dilden başka milletler arası ortak olan dillerin öğrenilmesi gerekmektedir. Bir yabancı dil öğrenmek yeni bir insan olmaktır" (Barın, 2004: 20). Aynı zamanda bilgiyi öğrenme stratejileri ve öğrenme stilleri yaşam boyu devam eden bir süreç olarak düşünülmelidir. "İki dilli çocuklar, diğer çocuklara nazaran, daha yaratıcı 
bir zekâya, daha esnek bir bilişsel yapıya, daha yaratıcı bir eleştirel düşünce yapısına sahiptirler" (Kabaday1, 2008; aktaran Arslangilay, 2013: 24).

Özbay (2006) anadilinin işlevsel özelliklerini iyi kavrayan bir öğrencinin, diğer dilleri öğrenirken aldığı mesajları algısına daha doğru yerleştirip kullanabildiğinden söz etmiştir. Böylece öğrenci, anadil eğitimi çalışmalarında hangi teknik ve yöntemleri kullandığına dair karar verebilir ve yabancı dil öğreniminde de bu yöntemlerden faydalanabilir. Neuner vd. (2009) çok dilliliğin, diller arası transferde çok önemli bir rol oynadığını vurgulamıştır. "[...]Yabancı bir dil ya da diller, bize bu dillerin dünyayı algılama biçimlerini ve değer sistemlerini tanıttığından, hem o dillerin kültürleriyle donanmış kişilerle her alanda daha iyi iletişim kurabilmemizi sağlıyor, hem de kendi düşüncemizi geliştiriyor, çevremizi genişletiyor, bunun da ötesinde kültürler arasında değişik ve aynı olan yanlar kendi varlığımızın, kendi benliğimizin bilincine daha iyi varmamıza ve kendi konumumuzu daha iyi belirlememize yardımcı oluyor" (Ozil, 1991: 96; aktaran İşcan, 2011: 29).

Er (2006) öğrencilerin farklı kültürleri tanıyarak dil öğrenmeye yönelik motive olduklarını ifade etmiştir. Buradaki bulgulara dayalı olarak, dilin kültür aktarımında etkili bir araç olduğu, çok kültürlü toplumlarda yaşayan bireylerin rahat iletişim kurdukları, empati becerilerini geliştirdikleri ve bu durumun dil öğrenmeyi olumlu etkilediği görünmektedir. Çok kültürlü olmak çok dil bilmeyi ifade ettiği gibi, öğrenilen dillerin birbirleri ile olan ilişkileri de, dil öğrenmede önemlidir. Birden fazla dil öğrenimi birbirini takip eden sistemler zinciridir. L1 öğrencinin öğrencinin doğuştan edindiği anadildir. L2, ögrencinin L1'den sonra öğrendiği ilk yabanc1 dildir. L3 ise, öğrencinin L1'den sonra öğrendiği ikinci yabancı dildir. L1 öğrenilmez, ailede doğumdan itibaren edinilir. Bu durum bireyin bebeklik çağından itibaren dil gelişim süreçlerini kapsamaktadır. Ancak L2 ve L3 bir öğrenme ortamı içerisinde gerçekleşebilir. $\mathrm{Bu}$ durum bireylerin L2 ve L3 öğrenme becerilerini nasıl geliştirdiklerini de göstermektedir.

Demirel (2008) L2'de etkili olan öğrenme stratejilerinin L3 öğreniminde belirleyici olduğunu belirtmiştir. Bu görüşe göre L3 bireyin öğrendiği birinci yabancı dilden sonraki tercihidir. L3, L2'nin öğrenme stratejileri, yöntemleri, deneyimleri ile zenginleştirilebilir. Aynı zamanda L3 öğrenimi, L1 ediniminin özdeş süreçlerinden geçebilir. Başka bir deyişle taklit veya yineleme yoluyla ikinci bir dili öğrenecek olan öğrenci kendine özgü öğrenme stillerini keşfedebilir.

Her insanın farklı bir öğrenme stiline sahip olduğu bilinmelidir. "Herhangi bir sınıf ortamında tek bir öğrenme stiline sahip bireyler değil, farklı öğrenme stillerine sahip bireylerin bulunabileceği (Peker vd. 2004) unutulmamalıdır" (Tatar ve Tatar, 2007: 128). Bu bireysel farklılıklar göz önünde bulundurulduğu zaman yöntem ve tekniklerin uygulanmasında da çeşitlilikler görülebilir. "Bazı yöntem ve tekniklerin yabancı dil öğrenmeyi kolaylaştırdığını söylemek mümkündür” (Cesur, 2008: 3). Yöntem ve tekniklerin çeşitliliğinin öğretim ortamını da zenginleştirdiği söylenebilir. "Öğrenme stilleriyle ilgili çalışmaların temelinde, bireysel farklılıkların öğrenme ortamında bir zenginlik olduğu düşüncesi yatmaktadır" (Gencel, 2007: 121). Öğrenme stillerine göre yabanc1 dil öğretimine yönelmek, daha çok öğrenme merkezli olabilmeyi de getirebilir. "Öğrenme merkezli öğretim ortamlarına geçilmesi, öğrenen özelliklerine odaklanmayı da beraberinde getirmiştir. Ayrıca bilimsel ve teknolojik gelişmeler ile öğrenme ortamları da çoğalmıştır. Bu süreçle birlikte bilgiye ulaşma yolları ve olanakları artmış ve öğrenmede bireysel özellik ve farklılıklar önem kazanmıştır.

"Öğrenme stili bireyin yaşamında önemli bir yere sahiptir. Birey kendi öğrenme stilini bildiğinde, öğrenme sürecinde bu stili devreye sokacaktır. Böylece, hem daha kolay, hem daha çabuk öğrenecek ve büyük bir olasılıkla öğrenme sürecinde başarılı olacaktır. Yapılan araştırmalar, bireylerin baskın olan bir öğrenme stilinin yanında bir başka öğrenme stilinin de olduğunu göstermektedir. Yani, bir bireyin bir ya da daha çok öğrenme stili olabilir. Bireyin birden çok öğrenme stili olduğunda, bunu kullanma dereceleri değiş̧ebilir" (Güven ve Kürüm, 2006: 77). Bireyin öğrenme stili konusundaki farkındalığ öğrenme sürecine de olumlu etki edecektir. Işık (2013) Yabancı dil öğrenirken insanın beyninde dil edinimi için özelleşmiş bir dil edinim cihazı olduğunu ve doğuştan gelen potansiyelin bütün dil öğrenme olayını kontrol edip, yönlendirdiğini ifade etmiştir. Bundan dolayı bu potansiyelin aktif hale getirilmesinin çok önemli olduğunu, bu potansiyeli kazanan bireylerin yaşam boyu dili kullanabileceğini belirtmiştir.

Öğrenme başarısı öğrenme stilleri ile orantılı olabilir. "Yapılan araştırmaların büyük çoğunluğu, öğretim ortamları, öğrencilerin öğrenme stilleri dikkate alınarak tasarlandığında öğrenme başarısının arttığını göstermektedir" (Hein ve Budny, 2000; aktaran: Kılıç ve Karadeniz, 2004: 133). Öğrenme stilleri farkındalığı öğrenme ortamını zenginleştirebilir ve öğretenin bakış açısını da geliştirebilir. “Ayrıca, öğrenme stillerini bilmek ve öğrenme-öğretme etkinliklerini buna uygun tasarlamak, öğrenme 
güçlüğü var diye nitelendirdiğimiz pek çok öğrencinin gerçekte bir öğrenme güçlüğü olmadığını, uygun ortamlar ve uyarıcılar sunulduğunda böyle nitelenen öğrencilerin de kolaylıkla öğrenebildiklerini gösterebilir" (Veznedaroğlu ve Özgür, 2005: 3). Bu konuda eğitimcilere önemli bir görev düştüğü söylenebilir. "Öğretmenler, öğrencilerinin hangi tür öğrenme stillerine sahip olduklarını bilmelidirler. $\mathrm{Bu}$ amaçla eğitim yılının başlangıcında tüm sınıflara öğrenme stili envanterleri uygulanmalıdır. Öğrencilerin öğrenme stillerini dikkate alan öğretim yöntemleri geliştirilmelidir”' (Tatar ve Tatar, 2007: 129). Yapılan çalışmalar öğretim sürecini hızlandırabilir ve bireyi geliştirdiği gibi öğretim ortamını da zenginleştirebilir. "Bireylerin nasıl öğrendikleri ve bunlara etki eden etmenlerin ne olduğunun bilinmesinin, etkili öğrenme sürecini kolaylaştırması beklenmektedir. Bu açıdan bakıldığında bireylerin nasıl öğrendiği ile ilgili boyutta öğrenme stili kavramı, bu sorunun açıklanmasına yardımcı olabilir." (Sümer, 2015: 52).

$\mathrm{Bu}$ çalı̧̧mada elde edilen verilerden hareketle, L3 eğitimi alan öğrencilere, hem L1 hem de L2 öğrenirken öğrenme stilleri konusunda farkındalık kazandırılmaları gerektiği düşünülebilir. L3 eğitimi alan öğrenciler, L1 ve L2 dillerinde edinmiş oldukları öğrenme stillerinden faydalanarak içinde bulundukları öğrenme sürecinin farkına varabilirler. Böylece öğrencilerin ihtiyaçlarına uygun öğrenme ortamları da sağlanabilir. Öğrenme stillerine göre ders anlatmak isteyen bir öğretmenin de karşılaştığı güçlükler azaltılabilir ve eğitim kalitesi arttırılabilir. Öğrenciler L1, L2 ve L3 derslerinin amaçlarına yönelik planlanan bilgileri ögrenebilir ve yaşam boyu kullanmaya hazır olabilirler.

\section{YÖNTEM}

\subsection{Araştırmanın Modeli}

Bu çalışmada amaç, L3 olarak Almanca dersi gören öğrencilerin öğrenme stillerini belirlemektir. Bunun için L3 öğrenen öğrencilerin önce L1, L2 öğrenme stilleri belirlenmeye çalış1lmıştır. L1, L2 ve L3'ün öğrenme stilleri açısından birbirleri ile olan etki alanları çalışmada cevap aranan sorular arasındadır.

Araştırmada yer alan L1, öğrencilerin anadili olan Türkçe'yi, L2 birinci yabancı dil olan İngilizce'yi, L3 ise ikinci yabancı dil olan Almanca'yı ifade etmektedir. Araştırma durum çalışması olarak desenlendirildi. "Bir durum çalışmasının veri analizinde farklı birçok araç ve teknikle ilgili bilgi sahibi olmak bu süreci oldukça kolaylaştırır. Kullanılacak stratejiler ve teknikler belirlenmediğinde ise bu süreç oldukça zorludur. Bir durum çalışmasında neyin nasıl analiz edileceği ile ilgili genel bir analitik stratejinin bulunması mutlaka gereklidir" (Türkoğlu, 2015: 43). "Durum çalışması yapmak, süreçte devam eden güncel bir olayı derinlemesine incelemekte ilgilidir" (Yin, 2014; aktaran Akar, 2016: 130).

\section{2. Çalışma Grubu/ Evren- Örneklem}

Çalışmaya, Edirne'de özel bir okulda Türkçe, Almanca ve İngilizce bölümlerinde görev yapan üç öğretmen, 4., 5. ve 6. sinıflarda okuyan öğrenciler (n=111) katılmıştır.

\subsection{Veri Toplama Aracı}

$\mathrm{Bu}$ araştırmada hem nicel hem de nitel veriler toplanmıştır. Araştırmanın nicel verilerini Aşkar ve Akkoyunlu (1993) tarafindan çevrilen Kolb Öğrenme Stilleri Envanteri oluşturmaktadır. Bu envanter ile 4., 5. ve 6. sınıf öğrencilerinin L1, L2 ve L3'teki öğrenme stilleri belirlenebilmiştir. Ayrıca araştırmacı tarafından öğrencilerin demografik bilgileri ile L1, L2 ve L3'e yönelik öğrenme stili yeterliliklerine yönelik bilgiler alınmıştır. İkinci yabancı dilde öğrenme stillerinin belirlenmesine yönelik diğer nitel verileri L1, L2 ve L3 derslerinde öğretmenler ile bireysel görüşmeler, öğrencilerle ise hem bireysel hem de odak grup görüşmeleri yapılarak toplanmıştır. Yapılan görüşmeler araştırmacının defterine not edilerek ses kaydı yapılmıştır. Ayrıca öğrencilerin kendi oluşturdukları görsel ürünler öğrenme stilleri açısından değerlendirilerek araştırmacı tarafindan betimlenmiştir. Araştırmacı tarafından içerik analizi gereği nitel verilerin kavramsallaştırılması için yapılan tüm çalışmalar değerlendirilerek, temalara, alt temalara karar verilmiştir. Aşkar ve Akkoyunlu (1993) tarafından çevrilen ve güvenirlik geçerliliği test edilen Kolb Öğrenme Stilleri Envanterinin L1, L2 ve L3 için kullanımı uzman kişi tarafından SPSS 22.0 paket programı yardımı ile hesaplanmışıı (bkz. Tablo 1).

\subsection{Verilerin Toplanması ve Analizi}

Araştırmada nicel ve nitel veriler toplanarak analiz edilmiştir.

\subsubsection{Nicel Verilerin Analizi}


Aşkar ve Akkoyunlu (1993) tarafindan çevrilen ve güvenirlik geçerliliği test edilen Kolb Öğrenme Stilleri Envanterinin L1, L2 ve L3 için kullanımı uzman kişi tarafından SPSS 22.0 paket programı yardımı ile şu şekilde hesaplanmıştır:

Tablo 1.

L1, L2 ve L3 için uygulanan kolb envanterinin güvenirlik katsaylları

\begin{tabular}{ll}
\hline Dil & Güvenirlik \\
\hline L1 & 0,932 \\
L2 & 0,948 \\
L3 & 0,952 \\
\hline
\end{tabular}

Toplanan verilerin frekansı $\mathrm{T}$ değeri ile analiz edilmiştir. Cronbach's alfa katsayısı ölçeğin güvenirlik düzeyini vermektedir. Katsayı 0 ile 1 arasında değişmektedir ve katsayının 0,700'den büyük olması ölçeğin güvenirliğini göstermektedir.

\subsubsection{Nitel Verilerin Analizi}

Nitel araştırmalarda veri analizi bulgulara ve sonuçlara ulaşmayı sağlayan önemli bir süreçtir. Yıldırım ve Şimşek'e (2013) göre her nitel araştırmanın farklı özellikleri olabilir ve bu özellikler yeni, yaratıcı yaklaşımları ortaya çıkarabilir. Buna bağlı olarak, durum çalışmasının nasıl analiz edileceği ile ilgili strateji ve yöntemleri belirlemenin önemli olduğunu belirtmişlerdir.

4. sınıf öğrencilerinin ürünleri araştırmacının teorik bilgileri ile incelenmiştir ve öğrenme stilleri çeşitliliği değerlendirilmiştir. Böylece öğrencilerin öğrenme stilleri çeşitliliği ile öğretmenlerin öğrenme stilleri konusundaki yaklaşımlarını karşılaştırma firsatı sağlanmıştır.

Araştırmaya dahil olan 6. sınıf öğrencileri ile yapılan odak grup ve bireysel görüşmelerinin ses kayıtları alınarak, araştırmacının defterine not edilmiştir. Yapılan görüşmelerin transkriptleri oluşturulmuştur. 6. sınıf öğrencileri ile yapılan bireysel görüşmelerden elde edilen bilgileri doğrulamak amaciyla aynı öğrenciler ile odak grup görüşmeleri gerçekleştirmiştir. Öğrencilerin bireysel ve grup içerisinde öğrenme stilleri konusundaki görüşlerinin tutarlılığı incelenerek içerik analizi yapılmıştır.

Araştırmanın diğer nitel verileri L1, L2 ve L3 ders öğretmenleri ile bireysel görüşmeler yapılarak toplanmıştır. Böylece öğretmenlerin öğrenme stillerine yönelik farkındalıkları incelenmiştir.

\section{BULGULAR}

\subsection{Nicel Araștırmaya Yönelik Bulgular}

Öğrencilere kişisel bilgi formu arac1lığıyla cinsiyet, sınıf dağılımları, L1, L2 ve L3 bilgileri, L1, L2 ve L3'e göre kendilerini 0-100 aralığında nasıl değerlendirdikleri, L1, L2 ve L3'te öğrenme stili yeterliliklerini öz değerlendirme tablosunda (çok iyi, iyi, normal, kötü, çok kötü) nasıl buldukları sorulmuştur. Ancak bu çalışmada toplanılan bilgilerden sadece cinsiyet ve sınıf dağılımlarına yönelik iki veriye yer verilecektir.

Tablo 2.

Cinsiyet

\begin{tabular}{lll}
\hline Cinsiyet & $\mathrm{n}$ & $\%$ \\
\hline Kiz & 58 & 52,3 \\
Erkek & 53 & 47,7
\end{tabular}

Ankete katılan 111 öğrencinin \%52,3'ü kı, \%47,7'si erkektir. Cinsiyet netlerinin orantısal olduğu görülmektedir. 
Tablo 3.

Sinıf Dă̆ılımı

\begin{tabular}{lcc}
\hline Siniflar & $\mathrm{n}$ & $\%$ \\
\hline 4.sinif & 23 & 20,7 \\
5.sinif & 58 & 52,3 \\
6.sinif & 30 & 27,0 \\
toplam & 111 & 100 \\
\hline
\end{tabular}

Katılımcıların \%20,7'si 4. sınıf, \%52,3’ü 5. sınıf, \%27,0’1 6. sinıf öğrencisidir. Öğrenciler arasında yaş grupları açısından farklılıklar bulunmaktadır. 4. sınıf öğrencileri 10-11, 5. sınıf öğrencileri 11-12, 6. Sinıflar ise 12-13 yaşları arasındadır.

Kolb Öğrenme Stilleri Envanterine katılan 111 öğrencinin \%67,6's1 L1'de en iyi öğrenme yolu olarak öğrendiklerini çok uygulamaktadır, \%17,1'i orta, \%9,9'u biraz, \%5,4'ü en az uygulamaktadır. Ankete katılan tüm öğrencilerin $\% 68,5$ 'i L2'de en iyi öğrenme yolu olarak öğrendiklerini çok uygulamaktadır, \%18,9'u orta, \%8, '’ i biraz, \%4,5'i en az uygulamaktadır. Ankete katılanların \%67,6's1 L3'de en iyi öğrenme yolu olarak öğrendiklerini çok uygulamaktadır, \%13,5'i orta, \%14,4'ü biraz, $\% 4,5$ 'i en az uygulamaktadır. Öğrencilerin en iyi öğrenme yolu olarak L1, L2 ve L3'te benzer oranlarda öğrendiklerini uyguladıkları görülmektedir.

Ankete katılan 111 öğrencinin \%67,6's1 L1'de en iyi öğrenme yolu olarak çok izlemekte, $\% 16,2$ 'si orta, \%7,2'si biraz, \%9,0'1 en az izlemektedir. Ankete katılan tüm öğrencilerin \%61,3'ü İngilizce'de en iyi öğrenme yolu olarak çok izlemekte, $\% 19,8$ 'i orta, $\% 10,8$ 'i biraz, $\% 8,1$ 'i en az izlemektedir. Ankete katılanların \%61,3'ü Almanca'da en iyi öğrenme yolu olarak çok izlemekte, $\% 18,9$ 'u orta, \%9,9'u biraz, \%9,9'u en az izlemektedir. Öğrencilerin L1'de en iyi öğrenme yolu olarak L2 ve L3'e göre daha fazla izlediği görülmektedir.

Ankete katılan 111 öğrencinin \%69,4'ü L1'de en iyi öğrenme yolu olarak, insanlarla konuyla ilgili çok konuşmakta ve iletişim kurmaktadır, $\% 15,3$ 'i orta, $\% 10,8$ 'i biraz, $\% 4,5$ 'i konuyla ilgili en az konuşmakta ve iletişim kurmaktadır. Ankete katılan tüm öğrencilerin \%63,1'i İngilizce'de en iyi öğrenme yolu olarak, insanlarla konuyla ilgili çok konuşmakta ve iletişim kurmaktadır, \%22,5'i orta, $\% 17,2$ 'si biraz, \%7,2'si konuyla ilgili en az konuşmakta ve iletişim kurmaktadır. Ankete katılanların $\% 62,2$ 'si Almanca'da en iyi öğrenme yolu olarak, insanlarla konuyla ilgili çok konuşmakta ve iletişim kurmaktadır, \%22,5'i orta, \%8,1'i biraz, \%7,2'si konuyla ilgili en az konuşmakta ve iletişim kurmaktadır. Öğrencilerin en iyi öğrenme yolu olarak L1'de L3'e göre daha fazla insanlarla iletişim kurma yolunu tercih ettikleri, yine L1 öğrenme yolunda L2'ye göre iletişimi daha fazla tercih ettikleri görülmektedir. Ancak L2 ve L3'te bu durum benzer oranlardadır.

Ankete katılan 111 öğrencinin \%69,4'ü L1'i öğrenirken çok gözlem yapmakta, \%15,3’ü orta, \%9,0'ı biraz, \%6,3'ü en az gözlem yapmaktadır. Ankete katılan tüm öğrencilerin \%67,6'sı İngilizce öğrenirken çok gözlem yapmakta, \%14,4'ü orta, \%9,0'1 biraz, \%9,0'1 en az gözlem yapmaktadır. Ankete katılanların \%64,0’1 Almanca öğrenirken çok gözlem yapmakta, \%18,0'1 orta, \%10,8'i biraz, \%7,2'si en az gözlem yapmaktadır. Öğrencilerin L1, L2 ve L3 öğrenirken benzer oranlarda gözlem yaptıkları görülmektedir.

Ankete katılan 111 öğrencinin \%64,9’u L1'inin en iyi izleyerek öğrenildiğine çok katılmakta, $\% 24,3$ 'ü orta, \%7,2'si biraz, 3,6'sı en az katılmaktadır. Ankete katılan tüm öğrencilerin \%61,3’ü İngilizce'nin en iyi izleyerek öğrenildiğine çok katılmakta, \%24,3'ü orta, \%9,9'u biraz, 4,5'i en az katılmaktadır. Ankete katılanların \%53,2'si Almanca'nın en iyi izleyerek öğrenildiğine çok katılmakta, \%29,7'si orta, \%13,5'i biraz, 3,6's1 en az katılmaktadır. Öğrencilerin L1, L2 öğrenirken L3'e göre daha fazla izleyerek öğrendikleri görülmektedir.

Ankete katılan 111 öğrencinin \%61,3'ü L1'i öğrenirken konuyu kendi içerisinde küçük bölümlere ayırmakta, \%17,1'i orta, \%9,0'1 biraz, \%12,6's1 en az ayırmaktadır. Ankete katılan tüm öğrencilerin \%59,5'i İngilizce öğrenirken konuyu kendi içerisinde küçük bölümlere ayırmakta, \%15,3'ü orta, \%9,9'u biraz, \%15,3'ü en az ayırmaktadır. Ankete katılanların \%49,5'i Almanca öğrenirken konuyu kendi içerisinde küçük bölümlere ayırmakta, \%26,1'i orta, \%9,9'u biraz, \%14,4'ü en az ayırmaktadır. Katılımcıların L1 öğrenirken L3'e göre daha fazla konuyu kendi içerisinde küçük bölümlere ayırdığ1, aynı durumun L2'de L3'e göre daha fazla olduğu görülmektedir. 
Ankete katılan 111 öğrencinin \%55,0'1 L1'i öğrenirken duygularıyla çok hareket etmekte, $\% 23,4$ 'ü orta, \%9,9'u biraz, \%11,7'si duygulariyla en az hareket etmektedir. Ankete katılan tüm öğrencilerin \%50,5'i İngilizce öğrenirken duygularıyla çok hareket etmekte, \%24,3'ü orta, \%12,6's1 biraz, \%12,6'sı duygularıyla en az hareket etmektedir. Ankete katılanların \%49,5'i Almanca öğrenirken duygularıyla çok hareket etmekte, $\% 21,6$ 'sı orta, \%13,5'i biraz, \%15,3'ü duygularıla en az hareket etmektedir. Öğrencilerin L1 öğrenirken, L3'e göre daha fazla duygularıyla hareket ettikleri, ancak L2 ve L3 öğrenmede bu durumun benzer özellikler gösterdiği görülmektedir.

\subsection{Nitel Araştırmaya Yönelik Bulgular}

$\mathrm{Bu}$ bölümde elde edilen verilerin (öğretmenler ile bireysel görüşmeler, öğrencilerle bireysel ve odak grup görüşmeleri, öğrenci ürünlerinin betimlenmesi) analizleri yapılmıştır. $\mathrm{Bu}$ analizlerin yorumlanması, araştırmacının öğretim verdiği okuldaki gözlem ve deneyimleri ile birleştirilmiştir. Burada, nitel araştırmaya yönelik bulguların, sadece öğretmen ve öğrenciler ile yapılan görüşmeler ve öğrenci çalışmalarına yönelik kısımlarına yer verilmiştir.

\subsection{1. Öğretmenler İle Yapılan Görüşmeler}

Burada öğretmenler ile yapılan bireysel görüşmeler sonucu, öğretmenlerin öğretme yöntemlerine yönelik bulgulara yer verilmiştir. Burada öğretmenlerin öğretme yöntemini içeren ifadeleri belirtilmektedir. "Benim seçtiğim yöntemler sürekli değişiyor. Çünkü her geçen yıl nesil değişiyor ve beklentiler de değişiyor. Bu sebeple yöntemlerimi zenginleştiriyorum." (L1 Öğretmeni); "Mutlaka herkesin bir yöntemi vardır. Benimde bazı kullandığım yöntemler var. Zaten bu yöntemleri ister istemez deneyimlerle ediniyor insan." (L2 Öğretmeni); "Almanca öğretirken, hem ders saatimin az olmas1 nedeniyle, hem de akılda kalıcı olabilmem için mutlaka farklı yöntemler seçmem gerektiğini düşünüyorum." (L3 Öğretmeni).

Ayrıca öğretmenler ile yapılan bireysel görüşmeler sonucu, öğretmen görüşüne göre farklı öğrenme stillerine yönelik bulgulara yer verilmiştir."Gerçekten de hepsi farklı öğreniyorlar. Mesela bazen derste kitap okutuyorum. Bazı çocuklar okumak istemiyor, ya da okudukları metnin içeriğini tam anlayamıyorlar. Ancak okuttuğum kitabı aynı çocuk televizyonda izlediği zaman daha çok hoşuna gidiyor, onunla ilgili yorum yapıyor, içeriğini hemen anlatıyor. Ben çocukların farklı öğrenme stilleri olduğu görüşündeyim." (L1 Öğretmeni); "Çocuklar çok özeller, hepsine aynı tastan yemek verebiliriz ama farklı kaşıkları seçmeleri doğal bir durum." (L2 Öğretmeni); "Nasıl her insanın dış görünüşü farklıysa, öğrenme stilleri de farklı olabilir." (L1 Öğretmeni).

Bunun dışında öğretmenler ile yapılan bireysel görüşmeler sonucu, öğretmenlere göre L1, L2 ve L3 öğrenmenin öğrenme stilleriyle olan ilişkisine yönelik bulgulara yer verilmiştir. "Öğrenme stili söz konusuysa, bana gelen kişinin neye ihtiyacı olduğunu anlamalıyım. Dil öğretmek veya başka bir dersi öğretmek olsun, hiç fark etmez, burada önemli olan öğretilen dersin öğrenme stillerine uygun verilmesidir." (L1 Öğretmeni); "İngilizce öğrenmenin öğrenme stiliyle bağlantısı var. Neticede bu da bir ders ve bu dersin nasıl öğretildiği, kime öğretildiği oldukça önemli." (L2 Öğretmeni); "Almanca dersinde öğrencilerimin bazıları haftalık ders saati az olmasından dolayı derse karşı olumsuz tutum sergileyebiliyorlar. Ancak ben de onların birbirinden farklı öğrenme stillerini düşünerek, her ders onlara sabit bir yöntem uygulamak yerine farklı teknikler uygulamaya çalışıyorum.” (L3 Öğretmeni).

L1, L2 ve L3 öğretmenleri ile yapılan görüşmeler değerlendirildiğinde, öğretmenlerin öğrencilerinin öğrenme stilleri konusunda farkındalık geliştirdiğini, derslerinde öğrenme stillerine yönelik farklı yöntemlere yer verdiği söylenebilir.

\subsection{2. Öğrenciler İle Yapılan Görüşmeler}

Burada öğrenciler ile yapılan bireysel ve odak grup görüşmeleri sonucunda, öğrencilerin L1, L2 ve L3 derslerinde öğrenme stilleri farkındalıklarına yönelik bulgulara yer verilmiştir.

"Derslerde de okurken iyi anlarım." (Öğrenci 1); "Özellikle yabancı dil derslerinde film izlemekten çok hoşlanıyorum." (Öğrenci 2); "Bir şeyi öğrenmem gerekiyorsa sürekli not alıyorum." (Öğrenci 3); "Gördüğüm şeyleri hiç unutmuyorum. Herhalde fil hafizası derler ya, bende izleyince öyle oluyor." (Öğrenci 4); "Benim arkadaşlarım var, internetten arkadaşlar buldum arada sırada onlara yazıyorum." (Öğrenci 5); "Bende arkadaşım gibi internetten arkadaşlar buldum. Bazen görüntülü de konuşuyoruz ve gerçekten faydasını gördüm." (Öğrenci 6); "Ben galiba birilerine yazı yazmaktan hoşlanıyorum.” (Öğrenci 7); "Şark1 söylediğimiz derslerde daha çok eğleniyorum.” (Öğrenci 8).

Ayrıca, öğrenciler yapılan bireysel ve odak grup görüşmeleri sonucu, öğrencilerin L1, L2 ve L3 derslerinde kendi ögrenme stillerine rasladıkları durumlara yönelik bulgulara yer verilmiştir. "Siz gitar çalıyorsunuz. Bir şarkı çalmıştınız bize, kızlarla onu hep söyledik, hatta ben sözlerinin anlamını bile 
buldum öğretmenim. Sonra internetten de izledim, ezberledim. Orda ki kelimelerin anlamlarını da öğrendim.” (Öğrenci 1); "Öğretmenler bize sunum yaptırıyor, böyle olunca daha fazla çalışıyorum. Konuya önceden çalışıyorum sonra anlatırken aklımıza giriyor.” (Öğrenci 2); “Geçen yıl okulda tiyatro yaptık. İngilizce, Almanca, Türkçe tiyatrolar oldu. Tiyatro çalışırken tabi, cümleler ezberledik. Oradan öğrendiğim çok cümle var. Derslerde hep kullanıyorum." (Öğrenci 3);

Öğrenci görüşlerine göre, öğretmenlerin öğrenme stillerine yönelik yaklaşımları değerlendirildiğinde, öğrencilerin derslerde kendi ögrenme stillerine uygun yöntemlerle karşılaştıkları düşüncesine varılabilir.

\subsection{3. Öğrencilerin Sunumlarına Göre Öğrenme Stillerini Kullanımlarına Yönelik Bulgular}

L3 dersinde öğrencilerden "meslekler" konusuyla ilgili serbest bir sunum yapmaları istenmiştir. Yapılacak sunumun içeriğini öğrencilerin belirlemesi, konuyu istedikleri şekilde anlatmakta özgür oldukları ifade edilmiştir. Öğrencilerin çoğu "meslekler" konusunu farklı şekillerde ifade etmişlerdir. Araştırmaya katılan 8 öğrenci sunumundan sadece iki tanesi değerlendirildiğinde, öğrencilerin farklı öğrenme stillerine sahip oldukları söylenebilir.

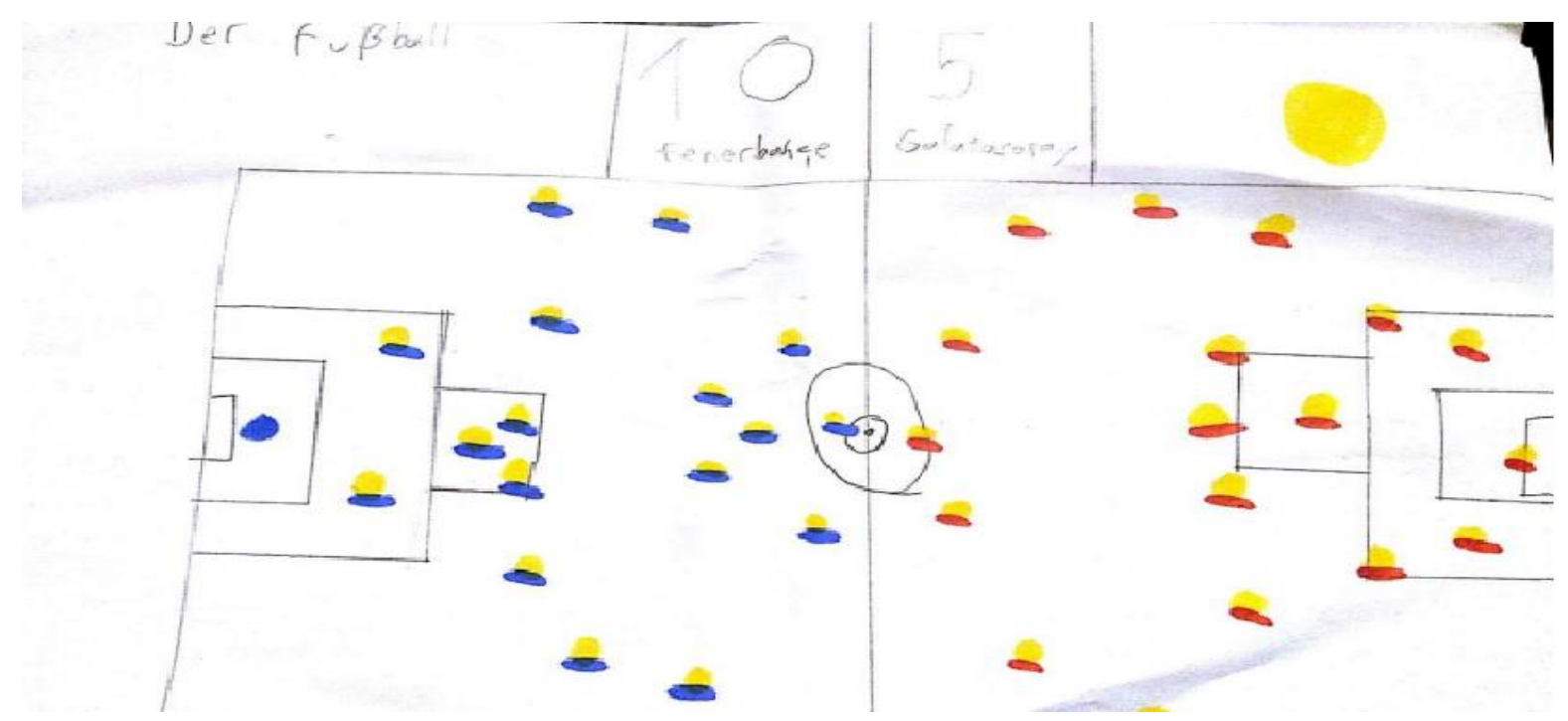

Resim 1. İşbirlikli, aktif yaşantı yoluyla öğrenen ve görsel öğrenme stiline sahip öğrenci çalışması

Resim 1'de öğrenci kendisini bir futbol yıldızı gibi düşünerek, sınıf içerisinde seçtiği kişilerden bir takım oluşturmuş ve kısa süreli futbol maçı ortamı oluşturarak onlarla futbol oynamıştır ve bu sırada arkadaşlarıyla diyalog kurmuştur. Vural (2013) Grasha-Riechmann öğrenme stili modelinin Türkiye koşullarında geçerli ve güvenilir bir ölçme aracı olarak kullanılabileceğini ifade etmiştir. Öğrencinin sunumunda takım arkadaşları ile birlikte çalışması onun Grasha-Riechmann'ın öğrenme stili modeline göre, işbirlikli öğrenen olduğunu gösterebilir. Sunumunu canlandırması onun aktif, uygulamayı ve risk almayı tercih ederek, Kolb öğrenme stillerine göre aktif yaşantı yoluyla öğrenmeyi seçtiğini gösterebilir. Yaptığı sunum planını resmetmesi ise onun görsel öğrenme stiline sahip olduğunu ifade edebilir. 


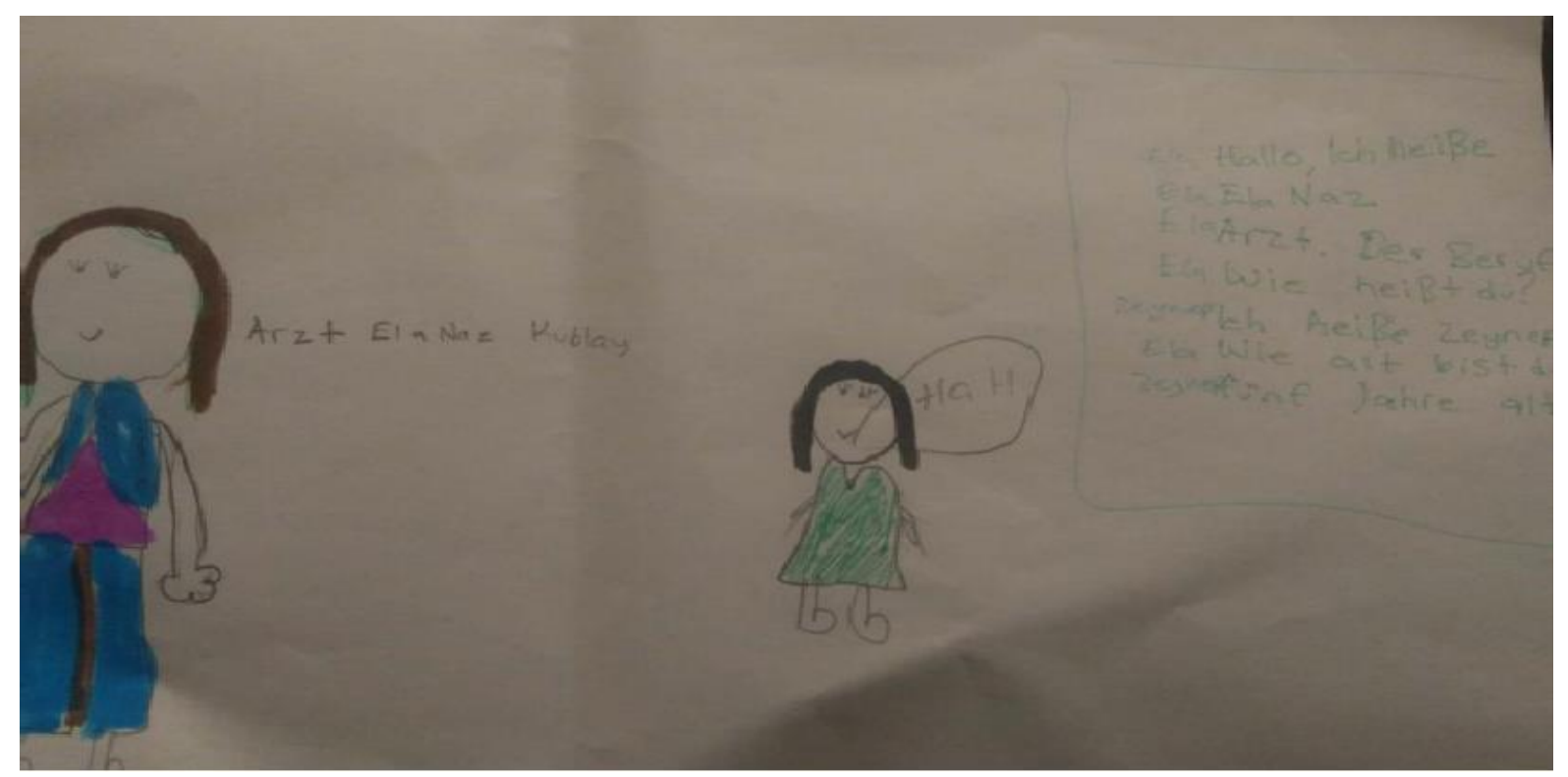

Resim 2. Görsel ve işitsel öğrenme stiline sahip öğrenci çalışması

Resim 2'de iki öğrenci birlikte çalışmak istemiş ve birbirlerine meslekleri hakkında sorular sormuşlardır. Konuşma etkinliğini kullanmaları onların işitsel öğrenme stillerini kullandıklarını gösterebilir. Daha sonra diyaloglarını anlatan resim de yapmışlardır. Bu etkinlikleri ise onların görsel öğrenme stillerini tercih ettiklerini gösterebilir. Öğrencilerin bir araya gelerek grup çalışması yapmış olmaları Grasha-Riechmann'ın öğrenme stilleri modeline göre işbirlikli öğrenme stillerine sahip olduklarını sahip olduklarını gösterebilir. Öğrenciler L3 olarak yazdıkları meslekleri L1 ile de ifade etmişlerdir. Bu durum L3 derslerinde L1 ile bağlantı kurduklarını göstermektedir.

\section{TARTIŞMA, SONUÇ ve ÖNERILER}

Öğretmenlerin öğrenme stillerine yönelik uygulamaları, onların pedagojik eğitimlerine, özerk öğrenme bilinçlerine ve Ortak Avrupa Çerçeve Kriterlerini öğrenmeleri ile de ilgilidir. Öğrenme stilleri günümüz çă̆daş eğitim anlayışına göre önemli bir yere sahiptir. Bu nedenle öğretmenler Kolb öğrenme stilleri envanterini öğrencileri tanımak adına sene başında yapmalıdır. Kayacık (2013) "Öğrencilerin Kolb Öğrenme Stillerine Göre Çalışma Alışkanlıkları, Ödev Yapma Motivasyonları ve Stilleri Üzerine Bir Çalışma" adlı yüksek lisans tezinde, Kolb öğrenme stilleri envanterinin öğretmenlere hali azırda neler yapıldığına dair teorik bir açıklama sağladığından söz eder. Yine Kayacık Kolb öğrenme stilleri envanterinin geri bildirim sağlayarak öğrenmeyi güçlendirdiğinden bahsetmiştir. Eğitimde çocuğa görelik ilkesi önemlidir. Bu nedenle çocuğun öğrenmesinin tam olarak sağlanması gerekmektedir. L1'de edinilen öğrenme stilleri deneyimlerinin daha sonraki yabancı dil öğrenme süreçlerine olumlu etkisi olduğu görülmektedir. Jimenez (2009) 'Mut zur Mehrsprachigkeit' adlı kitabında, birden fazla dili öğrenme sürecinden bahsetmiştir. Jimenez'de L1 ve sonrasında öğrenilen dilller arasında olumlu aktarmaların olabileceğini belirtmiştir. L1 öğretmenleri erken yaşta öğrencilerin öğrenme stillerini keşfetmelidir. Çünkü L1 ortamı, öğrencilerin bilişsel anlamda kendilerini en rahat ettikleri öğrenme ortamıdır. Daha sonra disiplinlerarası öğrenme ile bu deneyimler L1'den L2 ve L3'e aktarılır. Ayrıca çocuklara yabancı dil eğitiminde öğrenme süreci ilerledikçe öğrenme stillerinin değiş̧ip değişmediği de araştırılmalıdır. L1, L2 ve L3 dillerinin kendi aralarında olumlu transfer sağladığı unutulmamalıdır. Derslerde diller arası transferler kullanılmalıdır. Farklı ders materyallerinin yer aldığı ortamlarda, her öğrencinin stiline hitap eden ders ortamlarının olması onları öğrenme işinin içerisine yönlendirebilir ve öğrencinin yabancı dil öğrenme motivasyonunu arttırabilir. $\mathrm{Bu}$ nedenle öğretmenler öğrencinin öğrenme stilleri konusunda bilgi sahibi olmalıdır. L3'te öğrenme stilleri daha derinlemesine incelenmelidir. Bu konuda alan yazında daha fazla çalışmaların yer alması gerekmektedir.

Araştırmada öğrenme stillerinin L1, L2 ve L3'te benzerlik ve farkl11ıklar gösterdiği ve L1, L2 ve L3 birbirlerine olumlu transferler sağladığı bulgulanmıştır. Bu açıdan bakıldığında öğretmenlerin öğrencilerinin öğrenme stillerini bilmesi ve buna göre etkinlikler hazırlaması önemsenmelidir. Araştırmanın nicel bulguları, öğrencilerin L3 dersinde öğrenme stillerine yönelik farkındalıklarının yüksek olduğunu göstermektedir. Aynı durum L1 ve L2 dersleri içinde geçerlidir. Elde edilen bulgular, 
araştırmanın yapıldığı okulda, öğretmenlerin öğrenme stilleri konusunda yeterli alan bilgisine sahip olduklarını ve sınıflarında öğrenme stilleri konusunda farkındalık oluşturduklarını ortaya koymaktadır. “L1, L2 ve L3'te öğrenme stilleri nelerdir?" sorusunun yanıt1 olarak, L1'de kinestetik/ dokunsal, işitsel öğrenme stili, L2'de kinestetik/ dokunsal, işitsel öğrenme stili, L3'de kinestetik/ dokunsal öğrenme stili belirlenmiştir. L1 eğitiminde öğrencinin aldığı girdiler, öğrenme stilleri çerçevesinden geçerek o yönde şekillenir, bu durum öğrenilen sonraki yabanc1 diller içinde geçerli olabilir. Bu nedenle L1 eğitiminde edinilen deneyimler çok önemlidir. Öğrencinin L1'de farkına vardığ öğrenme stilleri daha sonra öğreneceği L2 ve L3'e katkıda bulunabilir. Böylece diller arasında olumlu aktarım gerçekleşerek yabanc1 dil öğrenmek daha pratik olabilir.

Araştırmanın nitel bulguları da öğrencilerin öğrenme stilleri konusunda farkındalık kazanmış olduklarını ve öğretmenlerin ders içi etkinliklerini öğrenme stillerine göre hazırladıklarını göstermektedir. Öğretmenler bireysel grup görüşmelerinde, öğrenme stilleri konusunda bilinçli olduklarını ve derslerde öğrenme stillerine yönelik etkinliklere yer verdiklerini ifade etmişlerdir. Aynı zamanda öğrenciler ile yapılan bireysel ve odak grup görüşmelerinde elde edilen ifadeler, öğrencilerin öğrenme stilleri konusunda farkındalık sahibi olduklarını göstermektedir. Araştırmacı ve yardımcı bir katılımcı tarafından öğrenci ve öğretmenlere yönelik yapılan ders gözlemleri de öğrenme stillerine yönelik ders ortamının sağlandığını doğrulamaktadır. Araştırmada nicel ve nitel bulguların birbirlerini desteklediğini göstermektedir. Bu durum, araştırma yapılan özel okulda uygulanan Uluslararası Bakalorya Programı (IB) ile açıklanabilir. Bakalorya programının hedefleri sorgulayan, bağımsız araştırma yeteneğine sahip, bilgili, ilke sahibi, duyarlı öğrenciler yetiştirmektir. Okulda verilen L1, L2 ve L3 dersleri bu hedefler doğrultusunda her sene başında güncellenmekte ve uygulanmaktadır. $\mathrm{Bu}$ süreçte öğretmenler Bakalorya programı hakkında her yıl düzenli olarak seminerlere katılmakta ve akademik anlamda kendilerini geliştirmektedirler. Bu araştırmada öğretmenlerin öğrenme stilleri konusunda bilinçli olması Bakalorya programının doğal bir uzantısı olarak ortaya çıkmaktadır. Bakalorya programı ile disiplinler arası öğrenim gören öğrenciler IB öğrenen profiline sahip olmaktadır. Bakalorya programının ilkelerine göre işlenen L1, L2 ve L3 dersleri, öğrencilerin kendi öğrenme süreçlerini, deneyimlerini dikkatle ele almasına yardımcı olur. Öğrenciler öğrenimlerini, kişisel gelişimlerini desteklemek için güçlü yönlerini ve sınırlılıklarını değerlendirebilirler. Böylece öğrenciler sorgulama ve araştırma için gerekli becerileri kazanmakta ve öğrenmede kendi öğrenme stillerinin farkında olmaktadırlar. Kendi öğrenme stillerinin farkında olan öğrenciler, öğrenmekten zevk alırlar ve bu öğrenme merakı yaşam boyu sürer. Aynı zamanda, kendi kültürlerini ve kişisel tarihlerini bilip, takdir eden öğrenciler, diğer bireylerin ve toplumların bakış açılarına, değerlerine ve geleneklerine açıktırlar. Farklı bakış açılarını bulmaya ve değerlendirmeye alışıktırlar ve bu konudaki tecrübelerini geliştirmeye isteklidirler. Bu tutumları ile öğrenciler çok kültürlü ve çok dilli bir profil edinirler. L1, L2 ve L3 dillerinin kendi aralarında olumlu transfer sağladığı unutulmamalıdır.

Öğrencilerin, "Duygularımı da öğrenmeye katarım" maddesine göre L1'de öğrenirken duyguları kullanma konusunda, L2 ve L3'e göre daha anlamlı bir fark gösterdiği görülmektedir. Bu düşünceden hareketle, öğrencilerin L1 öğrenirken, L2 ve L3'e göre duyguları ve sezgileriyle daha fazla hareket ettikleri düşüncesine varılabilir. Öğrenirken "Duygularıma ve sezgilerime güvenmektir", "Duygularımla öğrenirim", "Duygularıyla hareket eden biriyim", "Hissettiklerimi dikkate almaktır" maddelerinin yüzdelik değerleri ise orantısal olarak birbirlerine daha yakındır. Bu verilere göre, öğrencilerin L1'de, L2 ve L3'e göre duyguları ve sezgileri yoluyla öğrenmeye daha açık oldukları az farkla görülmektedir. Buna bağlı olarak L2'de duyguların L3'e göre yine az farkla öğrenmeye daha fazla yardımcı bir araç olduğu düşünülebilir. Anket genelinde aynı amacı araştıran 5 madde dikkate alındığında, elde edilen yüzdelik değerlere göre L1, L2 ve L3 arasında anlamlı bir fark görülmemiştir, böylelikle bir insan duygularıyla öğrenmeye açıksa, buna öğrendiği diğer dillerde de açık olabilir. Öğrencilerin benzer duygusal öğrenme tarzına sahip olması, aslında araştırmaya konu olan diller arasında anlamlı bir bağ olduğunu gösterebilir. Çünkü her üç dilin, öğrencilerin benzer his ve algılarına hitap ettiği söylenebilir.

Öğrenirken, "Konuyla ilgili öğrendiğim ş̧eyleri yapmaktan/uygulamaktan hoşlanırım" maddesine göre katılımcıların çoğunluğunun çekingen olmadıkları görülmekte ve derslerde aktif şekilde yaparak, yaşayarak uygulamayı tercih ettikleri neticesi elde edilmektedir. Bu durum öğrenmeye hazır olma durumu ile ilgilidir. Yaparak ve yaşayarak öğrenen bireylerin mantıksal analizlerden çok, duygularına dayalı olarak hareket ettikleri düşünülebilir. En güçlü yönleri ise iş bitiricilik, liderlik ve risk almaya istekli olmalarıdır. Bu öğrenme stiline sahip bireyler, yeni planlar kurmaktan ve yeni yaşantılar ortaya koymaktan zevk duyarlar. Aksoy (2012) "Yabancı dil öğreniminde kaygı, utangaçlık, strateji ve akademik başarı arasındaki ilişki" adlı doktora çalışmasında yabancı dil öğrenmede 
utangaçlık ve kaygı duyan öğrencilerin akademik başarısında anlamlı bir düşüş olduğu sonucuna ulaşmıştır. Öğrencilerin çekingen olmamaları, öğretmenlerin ders içi yaklaşım ve tutumları ile ilgili olabilir. Bu tutumlar öğrencilerin düşüncelerini rahatça ifade edebilmeleri ve doğrudan öğrenme işinin içinde düşünmeden yer alabilmeleri ile ilgili olabilir. $\mathrm{Bu}$ nedenle öğrencilerin kayg1 ve çekingenliklerinin en aza indirilmesi için öğretmenlerin bu konuda onları rahatlatması ve hata yapmaktan çekinmemeleri ve bunun doğal bir süreç olduğunu belirtmeleri gerekebilir

Öğrenirken "Derse katılmadan izlerim", en iyi öğrenme yolum "İzlemektir", en iyi öğrenme yolum "Konuyla ilgili gözlem yapmaktır", öğrenirken "Gözlem yapan biriyim", "Derse katılmadan sessizce dinlerim" maddelerine göre, katılımcıların L1, L2 ve L3 öğrenirken izleme ve dinleme oranları arasında belirgin farklar yoktur. Böylelikle öğrencilerin L1'den sonra öğrenecekleri herhangi bir dilde dinleme ve izleme yolunu aynı oranda kullanacakları düşüncesine varılabilir. Elde edilen verilerin benzer sonuçlar içermesi, L1'de var olanın devamını getirme niteliği taşıyabilir. Öğrencinin daha sonra alacağı yabanc1 dil eğitimi L1 eğitimine destek amaçlı gidebilir. Ancak bu benzeşik sonuçlara bakıldığında, her öğretmenin ayrı bir öğretme stili olduğu düşünüldüğünde, üç dildeki öğrenme stilleri arasında anlamlı bir fark olması gerektiği fikrine varılabilir. Öğrenme stilleri bireysel ise, her yabancı dil eğitimi de yeni bir bireysellik anlamı taşıyabilir, bağımsız bir ekol olabilir ve öğrenme stillerine farklı katkılarda bulunabilir. Öğretmenler risk alarak öğrenme stillerine farklı yönler verebilirler. Örneğin L3 öğretmeni, dersinde müziği kullanarak L1 ve L2'ye göre öğrenirken dinleme yolunda anlamlı bir fark oluşturabilir veya L2 öğretmeni dersiyle ilgili kısa filmler izleterek, L3 ve L1'e göre anlamlı fark oluşturabilir. Burada öğretmenlerin yeterlilikleri, bakış açıları, bilinçleri de aynı zamanda öğrencinin öğrenme stillerine katkıda bulunabilir.

Öğrenirken "Anlatılan fikirleri (konuları) tek tek ele almaktır" maddesine göre katılımcıların fikirleri L1, L2 ve L3'te aynı oranda tek tek ele aldıkları görülmektedir. Öğrenenlerin konuları tek tek ele almaları, bilgiyi bir bütün olarak değil, parçalar halinde, ayrı ayrı ele almaları ile ilgilidir. Aynı zamanda öğrencilerin, öğrenirken "Konuyu kendi içinde küçük bölümlere ayırırım" maddesine verdikleri yanıtların verileri dikkate alındığında, öğrencilerin L1, L2 ve L3'de konuları benzer oranda küçük bölümlere ayırdıkları görülmüştür. Bu sonuç diller arasında anlamlı bir bağ olduğunu gösterebilir. Çünkü her üç dilin, öğrencilerin benzer çözümleme becerilerine hitap ettiği düşünülebilir. $\mathrm{Bu}$ sonuçlara göre öğrencilerin her üç dili öğrenirken, benzer zihinsel faaliyetler uyguladıkları söylenebilir. Öğrenciler bu sayede bilgiyi daha çabuk kavrayabilir, pratik düşünme becerisini kullanabilir.

Öğrenirken, "İnsanlarla konuyla ilgili konuşmak, iletişim kurmaktır" maddesine göre öğrencilerin L1'de, L2 ve L3'e göre daha çok iletişim kurma yolunu seçtiği görülmektedir. Dil öğrenmenin en nitelikli ve doğru yolunun o dili kullanmak ve iletişim kurmakla mümkün olabileceği düşünüldüğünde, L2 ve L3'ün bu anlamda L1'e göre daha zayıf kaldığg söylenebilir. Ancak L1'deki iletişim kurma düşüncesinin çokluğu, dilin L1 olmasıyla yakında ilişkili olabilir. Çünkü L2 ve L3'te de iletişim becerisinin daha az tercih edilmesi, öğrencilerin o dili bilmemelerinden ve yeni öğrenmelerinden kaynaklı çekinceleri, başarma duygularının L1'e göre daha az olacağı düşünceleri ve bu yönde gelişen isteksizliklerine bağlı olabilir. İletişim kurarak öğrenme yolu öğrenme stillerinden biridir ve dil öğrenmede etkili bir yol olduğu düşünülebilir. Ancak burada asıl görev yine öğretmenlere düşmektedir. L1'den sonra öğrenilen her yabancı dil öğretmeni ders içerisinde farklı öğrenme stillerine yer vererek, farklı öğrenme yol ve tarzlarını deneyebilir. Böylelikle öğrenciler yabancı dilde daha katılımcı olabilir ve bu anlamda öğrenme istekleri artabilir. Öğretmenler öğrencilerin dili kullanırken yaşamış oldukları olumsuz anlarda yardımcı, destekçi konumda yer alabilir. Bu durum öğrencinin dil öğrenmeye karşı olumlu tutum geliştirmesini sağlayabilir.

Çalışmanın nicel verilerine bakıldığında, katılımcıların büyük bir çoğunluğu dinleyerek ve izleyerek öğrenmeyi, diğer öğrenme yollarına göre daha az tercih etmektedir. Ancak bu durumun çalışmaya katılan öğrencilerin kişisel öğrenme tarzlarına bağlı olduğu da unutulmamalıdır. Aynı çalışma farklı okullarda, farklı yaş gruplarında, farklı kültürel dokularda tekrarlandığında farklı sonuçların çıkabileceği de göz önünde bulundurulmalıdır.

Araştırmacı, nitel araştırmaya yönelik öğrenme stillerinin farklılı̆̆ını ortaya koymak için, 4. sınıf öğrencileri ile L3 dersinde meslekler konusu ile ilgili sınıf içi bir etkinlik gerçekleştirdi. Bu etkinlikte öğrenciler meslekler konusunu kendi istedikleri şekilde anlatmakta özgür bırakıldılar. Araştırmaya katılan öğrencilerin sunumları değerlendirildiğinde tüm öğrencilerin, sunumlarını işbirlikli, aktif yaşantı yoluyla öğrenen ve görsel, işitsel görsel öğrenme stilleri ile ifade ettikleri görülmektedir (Resim 1, Resim 2). Tatar ve Tatar (2007) her insanın farklı öğrenme stillerine sahip olduğundan bahsetmiştir. Ayrıca bireysel farklılıklar göz önünde bulundurulduğu zaman yöntem ve tekniklerin uygulanmasında 
değiş̧iklikler görüldüğünü ifade etmiştir. 4. Sınıflarda yapılan sunumlar bazı öğrencilerin görsel öğrenme stillerinin yanı sıra başka öğrenme stillerine de sahip olduklarını göstermektedir. Güven ve Kürüm (2006) bireylerin baskın olan bir öğrenme stilleri yanında bir başka öğrenme stili de olduğundan söz etmiştir. Yani bireylerin birden fazla öğrenme stilleri olabilir ve bunları kullanma dereceleri farklılık gösterebilir. Bu durum doktorluk mesleğini hem resim yaparak, hem de arkadaşı ile birlikte resimdeki meslek hakkında diyalog kurarak sunan bir öğrencinin çalışması ile örneklendirilebilir (bkz. Resim 2). $\mathrm{Bu}$ sunumda öğrenci görsel öğrenme stiline sahip olduğu gibi, arkadaşı ile yapmış olduğu grup çalışması ile Grasha- Reichmann'ın öğrenme stilleri modeline göre işbirlikli öğrenme stili özellikleri taşıdığ işitsel öğrenme stili özelliği taşıdığını da göstermektedir. Bir başka öğrenci ise futbolculuk mesleğini hem görsel öğrenme stili ile ifade etmiş, hem de sınıf arkadaşlarıyla bir futbol takımı oluşturarak futbol oynamış ve bu sırada onlarla L3 aracıllğıyla diyalog kurmuştur. Öğrencinin futbol takımı kurması onun Grasha- Reichmann'ın öğrenme stilleri modeline göre işbirlikli öğrenen özelliği taşıdığını göstermektedir. Aynı zamanda arkadaşlarıyla konuşurken L3'ü kullanması ise işitsel öğrenme stili özelliğine bağlıdır. Bu örnekler bir sinıfta öğrencilerin birden fazla öğrenme stillerine sahip olabileceğini göstermektedir. Tatar ve Tatar (2007) öğretmenlerin öğrencilerinin hangi tür öğrenme stillerine sahip olduklarını bilmelerinin öneminden söz etmiştir. Bunun için eğitim yılının başında öğrenme stilleri envanterlerinin uygulanması gerektiğine dikkat çekmiştir. Çünkü öğrencilerin öğrenme stillerinin bilinmesi, öğrenme ve öğretme tekniklerinin de gelişmesini sağlar. Bu şekilde, öğrenme güçlüğü var diye nitelendirilen birçok öğrencinin, doğru öğrenme stilleri yoluyla daha kolay öğrendikleri görülebilir. Öğrencilerin kendisine uygun öğrenme stillerini bilmesi, öğrenme gücünün artmasını sağlar. Aksi halde hem öğrenci, hem de öğretmen için olumsuz sonuçlar yaşanabilir. Öğrenciler derste sıkılabilir, korkabilir, ders çalışmak istemeyebilirler. Bu durum dolaylı olarak öğrenmeye engel olur. Bu nedenle öğrenme stillerinin farkında olunması çok önemlidir.

Daha sonra L1, L2 ve L3 öğretmenleri ile yapılan bireysel görüşmelerde, öğrenme stilleri bilinci, derslerde uyguladıkları öğrenme stilleri yöntemleri, L1, L2 ve L3 öğrenmenin öğrenme stilleri ile ilişkisi konuları ile ilgili düşünceleri soruldu. Bu düşüncelere göre L1, L2 ve L3 öğretmenlerinin özel okulda çalışma disiplinine bağlı olarak derslerde farklı yöntem arayışları içinde oldukları söylenebilir. Öğretmenlerin klasik sınıf ortamının aksine, öğrenci odaklı ve öğrenme stillerine hitap eden bir öğrenme ortamı oluşturma çabasında oldukları düşünülebilir.

Nitel araştırmanın verileri (öğrenci ürünleri, öğrencilerle yapılan bireysel ve odak grup görüşmeleri, bireysel öğretmen görüşmeleri) L1, L2 ve L3 öğrenme sürecinin, öğrenme stillerine bağl1 şekillendiğini göstermektedir. Aynı zamanda dillerin birbirleri ile olan transfer ilişkileri daha etkili bir öğrenme yolunun keşfedildiği görülmektedir. Öğretmenler öğrenme stillerinin insanın karakteristik özellikleri gibi doğal olduğunu, öğrencide bir ya da birden fazla olabileceklerini belirtmişlerdir. İncelenen 4. sınıf öğrenci sunumları da bu öğrenme stilleri özelliklerini kanıtlar niteliktedir. 4. Sınıf öğrencilerinin her gibi görsel öğrenme stillerine yönelik çalışmalar sunmuş ancak bazıları birden fazla öğrenme stilleri özelliği yansıtmışlardır. Öğretmenin burada öğrencilerini tanıması ve onlara özgü yöntemler geliştirmesi önemlidir. Tatar ve Tatar (2007) eğitim ortamlarının öğrencilerin öğrenme stillerine uygun olarak düzenlenmesinin katkı sağlayacağına değinmiştir. Böylece öğrencilerin başarısının artış göstereceğini, özgüven artışının olacağını, eğitimin öğrenci düzeyine uygunluğunun sağlanacağından söz etmiştir. Öğretmenlerin öğrenme stillerine yönelik uygulamaları, onların pedagojik eğitimlerine, özerk öğrenme bilinçlerine ve Ortak Avrupa Çerçeve Kriterlerini öğrenmelerine bağlıdır. Bu nedenle öğretmenin kendi öğrenme stillerini bilmesi de önemlidir. Öğretmenin öğrenme stillerini bilmesinin öğrencinin öğrenme stillerine etkisinin olup olmadığ 1 araştırılmalıdır veya öğretmenin öğrenme stilleri ile öğrencinin öğrenme stillerinin benzerlik veya farklılık gösterip göstermediği incelenebilir. Öğrenme stilleri günümüz çağdaş eğitim anlayışına göre önemli bir yere sahiptir. Bu nedenle öğretmenler Kolb öğrenme stilleri envanterini öğrencileri tanımak adına sene başında yapmalıdır. Eğitimde çocuğa görelik ilkesi önemlidir. Bu nedenle çocuğun öğrenmesinin tam olarak sağlanması gerekmektedir. L1'de edinilen öğrenme stilleri deneyimlerinin daha sonraki yabancı dil öğrenme süreçlerine olumlu etkisi olduğu görülmektedir. L1 öğretmenleri erken yaşta öğrencilerin öğrenme stillerini keşfetmelidir. Çünkü L1 ortamı, öğrencilerin bilişsel anlamda kendilerini en rahat ettikleri ögrrenme ortamıdır. Daha sonra disiplinlerarası ögrenme ile bu deneyimler L1'den L2 ve L3'e aktarılır. Ayrıca çocuklara yabancı dil eğitiminde öğrenme süreci ilerledikçe öğrenme stillerinin değişip değişmediği de araştırılmalıdır. Derslerde diller arası transferler kullanılmalıdır. Farklı ders materyallerinin yer aldığı ortamlarda, her öğrencinin stiline hitap eden ders ortamlarının olması onları öğrenme işinin içerisine yönlendirebilir ve öğrencinin yabancı dil öğrenme motivasyonunu arttırabilir. 
Bu nedenle öğretmenler öğrencinin öğrenme stilleri konusunda bilgi sahibi olmalıdır. L3'te öğrenme stilleri daha derinlemesine incelenmelidir. Bu konuda alan yazında daha fazla çalışmaların yer alması L3'te öğrenme stillerinin belirlenmesine katkı sağlayabilir.

$\mathrm{Bu}$ düşüncelerden yola çıkarak, öğrenme stilleri dil öğrenimi gerçekleştikçe değişiklik gösterir mi, dil öğrenme yöntem ve geleneklerine bağlı mıdır soruları üzerinde düşünmek gerekebilir. L1 eğitiminde öğrencinin aldığı girdiler, öğrenme stilleri çerçevesinden geçerek o yönde şekillenir, bu durum öğrenilen sonraki yabancı diller içinde geçerli olabilir. Bu nedenle L1 eğitiminde edinilen deneyimler çok önemlidir. Öğrencinin L1'de farkına vardığı öğrenme stilleri, daha sonra öğreneceği dillerde öğrenme üzerinde katkıda bulunabilir. L1, L2 ve L3 dillerinin kendi aralarında olumlu transfer sağladığı unutulmamalıdır. Derslerde diller arası transferler kullanılmalıdır. Böylece dil öğrenimi aktarımlar sayesinde daha pratik ve etkili olabilir. Batı ekolü söz konusu olduğunda, farklı ders materyallerinin yer aldığı ortamlarda, her öğrencinin stiline hitap eden ders ortamlarının olması onları öğrenme işinin içerisine yönlendirebilir ve öğrenci motivasyonunu arttırabilir.

$\mathrm{Bu}$ araştırmanın öğrenci kitlesi L1, L2 ve L3’te daha çok kinestetik/ dokunsal öğrenme stilleri ile öğrenmektedir. L1, L2 ve L3 öğretmenleri derslerde öğrenme stillerine yönelik etkinliklere yer vermektedir. Ancak bu araştırmanın verileri ile genel bir sonuca varılamaz. Bu nedenle L3'te öğrenme stilleri daha derinlemesine incelenebilir. Farklı öğrenci kitleleriyle çalışıldığında benzer veya farklı sonuçlar elde edilebilir. Ancak bu konuda alan yazında daha fazla çalışmaların yer alması gerektiği söylenebilir. Bu araştırmada öğrenme stillerinin bilincinde bir eğitim öğretim ortamı ele alındı. Böylece olumlu bir eğitim öğretim ortamındaki etkiyi ve verimi hissederek, yapılanların altı çizildi ve bunun yaygınlaşması gerektiğini belirtildi. Ayrıca L1 ve L2 eğitimcilerine de katk1 sağlandı. Ancak öğrenme stilleri konusundaki çalışmaların devlet okullarında da ele alınması gerekmektedir. Bu tarz örnekler sadece özel okullar da mı görülebilir? Burada öğretmenlere önemli görev düşmektedir. Her öğrencinin farkl1 öğrenme stilleri olabileceğinin düşünülüp, bu farklılıklara hitap eden öğrenme ortamlarının geliştirilmesi, hem öğrenme sürecini hızlandırabilir, hem de öğretim ortamının homojen gruplara hitap ederek zenginleşmesini sağlayabilir.

\section{KAYNAKLAR}

Akar, H. (2016). Eğitimde Nitel Araştırma Desenleri. A. Saban ve A. Ersoy (Ed.), Durum Çalışması (s. 139-155). Ankara: Anı Yayınc1l1k.

Akkoyunlu, B. (1995). Bilgi Teknolojilerinin Okullarda Kullanımı ve Öğretmenlerin Rolü. Hacettepe Üniversitesi Eğitim Fakültesi Dergisi, 11, 105-109.

Aksoy, M. (2012). Yabancı Dil Öğreniminde Kaygı, Utangaçlık, Strateji, Ve Akademik Başarı Arasındaki İlişki. Yayınlanmamış Doktora Tezi, Ankara Üniversitesi Sosyal Bilimler Enstitüsü, Ankara, TR.

Arslangilay, A. S. (2013). 3. Kuşak Türk Çocukları ve İki dilli-İki kültürlü Eğitim Modelleri (Hessen Eyaleti Koala Projesi). Yayınlanmamış Doktora Tezi, Gazi Üniversitesi, Ankara, TR.

Aşkar, P., ve Akkoyunlu, B. (1993). Kolb Öğrenme Stilleri Envanteri. Eğitim ve Bilim, 87(17), 37-47.

Ayaz, C. (2016). Öğretmenlerin Yaşam Boyu Öğrenme Eğilimlerinin Bazı Değişskenler Açısından Incelenmesi, Yayınlanmamış Yüksek Lisans Tezi, Bartın Üniversitesi, Bartın, TR.

Balcı, Ö. (2013). Öğrenme Stillerine Dayalı Etkinliklerin İngilizce Dersinde Öğrencilerin Okuduğunu Anlama Becerilerine Ve Öz-yeterlik Algılarına Etkisi. Yayınlanmamış Doktora Tezi, Necmettin Erbakan Üniversitesi, Konya, TR.

Barın, E. (2004). Yabancılara Türkçe Öğretiminde İlkeler, Türkiyat Araştırmaları Dergisi, 1, 19-30.

Cesur, M. O. (2008). Üniversite Hazırlık Sinıfi Öğrencilerinin Yabancı Dil Öğrenme Stratejileri, Öğrenme Stili Tercihi ve Yabancı Dil Akademik Başarısı Arasındaki Açılklayıcı ve Yordayıcı İlişkiler Örüntüsü. Yayınlanmamış Doktora Tezi, Yıldız Teknik Üniversitesi, İstanbul, TR.

Demirel, Ö. (2008). Karşılaştırmalı Eğitim, Ankara: Pegem A Yayıncılık.

Er, K. O. (2006). Yabancı Dil Öğretim Programlarında Kültürün Etkileri. Ankara Üniversitesi Eğitim Bilimleri Fakültesi Dergisi, (39)1, 1-14. 
Gencel, İ. E. (2007). Kolb’un Deneyimsel Öğrenme Kuramına Dayalı Öğrenme Stilleri Envanteri-III'ü Türkçeye Uyarlama Çalışması. Dokuz Eylül Üniversitesi Sosyal Bilimler Enstitüsü Dergisi, (9)2, 120-139.

Güven, M. (2004). Öğrenme Stilleri İle Öğrenme Stratejileri Arasındaki İlişki. Yayınlanmamış Doktora Tezi, Anadolu Üniversitesi, Eskişehir, TR.

Güven, M., ve Kürüm, D. (2006). Öğrenme Stilleri ve Eleştirel Düşünme Arasındaki İlişkiye Genel Bir Bakış. Anadolu Üniversitesi Sosyal Bilimler Dergisi, 6(1), 75-89.

Hufeisen, B. ve Neuner, G (Hg.) (2003), Mehrsprachigkeitskonzept - Tertiärsprachenlernen - Deutsch nach Englisch. Straßburg, Europarat (2004: englische Ausgabe, 2005: französische Ausgabe, 2005: 2. revidierte Auflage)

İşcan, A. (2011). Türkçenin Yabancı Dil Olarak Önemi. Uluslararası Avrasya Sosyal Bilimler Dergisi, 2(4), 29-36.

Işık, A. (2013). Yabancı Dil Nasıl Öğrenilmez? Nasıl Öğrenilir?, Ankara: Elma Yayınları.

Jimenez, I. (2009). Mut Zur Mehrsprachigkeit, Engelschoff: Ruffel Yayıncılık.

Kayacık, E. (2013). Öğrencilerin Kolb Öğrenme Stillerine Göre Çalışma Alışkanlıkları, Ödev Yapma Motivasyonları Ve Stilleri Üzerine Bir Çalışma, Yayınlanmamış Yüksek Lisans Tezi, Eskişehir Osmangazi Üniversitesi, Eskişehir, TR.

Kılıç, E., ve Karadeniz, Ş. (2004). Cinsiyet ve Öğrenme Stilinin Gezinme Stratejisi ve Başarıya Etkisi. Gazi Üniversitesi Gazi Eğitim Fakültesi Dergisi, 24(3), 129-146.

Neuner, G., Hufeisen, B., Kursisa, A., Marx, N., Koithan, U., ve Erlenwein, S. (2009). Deutsch als zweite Fremdsprache, München: Langenscheidt.

Özbay, M. (2006). Türkçe Özel Öğretim Yöntemleri, Ankara: Öncü Kitap.

Sümer, M. (2015). Farklı Öğrenme Biçimlerine Sahip Öğrenenlerin Web Destekli İşbirlikçi Öğrenme Araçlarından Wikiye İlişkin Görüşleri. Açıköğretim Uygulamaları ve Araştırmaları Dergisi, $1(2), 49-64$.

Tatar, E., ve Tatar, E. (2007). Öğrenme Stillerine Dayalı Öğretim. Journal of Qafqaz University, 20, 126-130.

Türkoğlu, E. M. (2015). Öğretmen Hesap Verebilirliği: Özel Bir Okulda Durum Çalışması. Yayınlanmamış Doktora Tezi, Eskişehir Osmangazi Üniversitesi, Eskişehir, TR.

Veznedaroğlu, L. ve Özgür, A. (2005). Öğrenme Stilleri: Tanımlamalar, Modeller ve işlevleri. Illkögretim-Online, 4(2), 1-16.

Vural, L. (2013). Grasha-Riechmann Öğrenme Stili Ölçeğinin Yapı Geçerliği Çalışmaları. Eğitimde Kuram ve Uygulama, Çomü Dergileri, 4, 481-496.

Yıldırım, A. ve Şimşek, H. (2013). Sosyal Bilimlerde Nitel Araştırma Yöntemleri, Ankara: Seçkin Yayıncılik. 